\title{
ANALISIS STUDI KELAYAKAN USAHA RUMAH BURUNG WALET DI KECAMATAN LALAN KABUPATEN MUSI BANYUASIN
}

\author{
Irsan \\ Email:irsan@unisti.ac.id \\ Universitas Sjakhyakirti Palembang
}

\begin{abstract}
ABSTRAK
Penelitian ini adalah untuk mengetahui bagaimana kelayakan usaha rumah burung walet (RBW) jika ditinjau dari aspek finansial. Lokasi penelitian di kecamatan Lalan kabupaten Musi Banyuasin Sumatera Selatan, dengan letak geografis berupa sawah dan perairan yang sesuai dengan habitat kehidupan burung walet. Penelitian ini menggunakan analisis deskriptif dari aspek finansial dengan 6 jenis kriteria investasi yaitu Payback Period (PP), Break Event Point (BEP), Net Present Value (NPV), Profitability Index (PI), Net Benefit/Cost Ratio (Net B/C), dan Internal Rate of Return (IRR). Dalam penelitian ini mengggunakan discount factor ( $d f)$ 12\%, hasilnya menunjukkan NPV sebesar $R p$ 231.901.674,- BEP sebesar 30,17 kg atau sebesar Rp 407.345.952,- Net $B / C$ sebesar 4.75, PI sebesar 2,2 dan IRR sebesar 26\%. Payback Period menunjukan bahwa jangka waktu pengembalian investasi selama 4 tahun 11 bulan. Berdasarkan analisis tersebut usaha RBW ini menguntungkan dan layak untuk diusahakan secara finansial.

Kata Kunci: Usaha Rumah Burung Walet, Aspek Finansial, Pengembalian Investasi
\end{abstract}

\section{PENDAHULUAN}

\section{Latar Belakang Masalah}

Pembangunan adalah proses perubahan dalam meningkatkan taraf hidup masyarakat, meningkatkan pertumbuhan ekonomi, mengurangi angka kemiskinan dan pengangguran. Secara umum pembangunan ini memiliki makna dalam upaya peningkatan dalam segala aspek kehidupan. Oleh karena itu, penanganan masalah ini diupayakan oleh pemerintah dengan menyalurkan berbagai bantuan dan subsidi serta membuka lapangan kerja dengan meningkatkan inisiatif dan kreatifitas masyarakat di samping memperluas kesempatan investasi langsung bagi semua pihak (Saparudin, 2012).

Masing-masing wilayah memiliki kemampuan dan potensi yang berbeda, dapat dimanfaatkan untuk membangun suatu perubahan yang lebih baik bagi 
Jurnal Ilmiah Akuntansi Rahmaniyah (JIAR)

Vol. 3 No.2, Juni 2020, $52-65$

Irsan

daerahnya sendiri. Kabupaten Musi Banyuasin provinsi Sumatera Selatan khususnya di kecamatan Lalan sangat prospek dan berpotensi dalam pengembangan usaha rumah burung walet $(\mathrm{RBW})$. Usaha nyata yang dapat dilakukan dalam pengembangan bidang ini salah satunya adalah dengan pembangunan dan pemberdayaan Usaha Kecil dan Menengah (UKM) peternakan sarang burung walet.

Kabupaten Musi Banyuasin dengan luas wilayah 14.265,96 km $\hat{\mathrm{A}}^{2}$ atau sekitar $15 \%$ dari luas Provinsi Sumatera Selatan terletak antara 1,3 $\hat{\mathrm{A}}^{\circ}-4 \hat{\mathrm{A}}^{\circ} \mathrm{LS}$ dan $103 \hat{\mathrm{A}}^{\circ}-104$ 45' BT. Musi Banyuasin merupakan daerah rawa dan sungai besar serta kecil seperti Sungai Musi, Sungai Banyuasin, dan sungai Batanghari Leko sangat cocok untuk pengembangan budi daya peternakan sarang burung walet.

Alasan meneliti usaha rumah burung walet ini karena mempunyai prospek yang potensial untuk dikembangkan. Terlebih kondisi lingkungan dan letak geografis yang sesuai dengan habitat dan sumber daya yang tersedia untuk mendukung kehidupan burung walet, terutama di kecamatan Lalan kabupaten Musi Banyuasin. Sarang burung walet merupakan komoditi ekspor, dengan tingkat harga yang cukup tinggi dan kompetitif. Walaupun harga jual sarang burung walet selalu berada pada tingkat harga yang relatif tinggi namun permintaan konsumen tetap tinggi. Berdasarkan latar belakang masalah dan pengalaman penulis sendiri sebagai salah satu peternak atau pengusaha rumah burung walet (RBW) di kecamatan Lalan tersebut diatas, maka penulis berminat untuk melakukan penelitan untuk mengetahui dan menganalisa studi kelayakan usaha tersebut dari aspek finansial.

\section{Perumusan Masalah}

Berdasarkan latar belakang dirumuskan permasalahan:"Seberapa besar kebutuhan dana investasi usaha peternakan walet di kecamatan Lalan kabupaten Musi Banyuasin dan bagaimana kelayakan usaha tersebut ditinjau dari aspek keuangan/finansial? “

\section{LANDASAN TEORI}

\section{Studi Kelayakan Bisnis}

Abdullah, 2017, menyatakan bahwa studi kelayakan bisnis adalah suatu kegiatan mempelajari dan meneliti secara sungguh-sungguh segala macam data dan informasi yang berkenaan dengan suatu kegiatan bisnis, dan selanjutnya data dan 
informasi itu dihitung dan dianalisis dengan suatu metode tertentu yang biasa dipakai dalam penelitian bisnis. Sedangkan Purwana (2017) menyatakan studi kelayakan bisnis merupakan suatu analisis terhadap viability (diteruskan atau tidak) suatu ide. Inti dari suatu studi kelayakan bisnis adalah mampu menjawab pertanyaan penting berikut, "should we procced with the proposed project idea?" Ini menunjukkan bahwa semua kegiatan dalam studi kelayakan mempunyai tujuan untuk menjawab pertanyaan tersebut. Tujuan ini menginformasikan pengetahuan kepada pihak yang melakuan usaha bahwa mengetahui lebih awal jika suatu ide bisnis tidak bekerja sesuai harapan. Dengan demikian penggunaan waktu, uang, dan sumber daya yang ada tidak sia-sia.

\section{Investasi dan Aspek Keuangan Dalam Studi Kelayakan Bisnis}

Menurut Abdullah, 2017, "konteks studi kelayakan bisnis investasi adalah menyangkut semua biaya yang diperlukan dalam pembangunan usaha yang dipergunakan untuk perangkat peralatan teknis dan modal kerja yang digunakan untuk menjalankan usaha". Kemudian juga meneliti seberapa besar pendapatan yang akan diterima jika proyek jadi dijalankan, seberapa lama investasi yang ditanamkan akan kembali, dari mana sumber pembiayaan dan bagaimana tingkat suku bunga yang berlaku (Purwana dan Hidayat, 2017). Sedangkan Kasmir dan Jakfar 2014, menyatakan bahwa aspek keuangan merupakan aspek yang digunakan untuk menilai keuangan perusahaan secara keseluruhan. Ada beberapa pengusaha menganggap bahwa aspek keuangan inilah yang paling utama untuk dianalisis karena dari aspek ini akan mendapatkan gambaran yang jelas hal-hal yang berkaitan dengan keuntungan usaha, sehingga aspek ini adalah salah satu aspek yang sangat penting untuk diteliti tingkat kelayakannya.

\section{Sumber dan Alat Ukur Investasi}

Menurut Kasmir dan Jakfar (2014) pembiayaan suatu usaha bersumber dari sumber dana yang diperoleh secara gabungan antar modal pribadi dan modal pinjaman. Masalah yang perlu diperhatikan berkaitan dengan perolehan modal adalah masa pengembalian modal dalam jangka waktu tertentu. Oleh karena itu, perlu dibuatkan estimasi pendapatan dan biaya sebelum usaha dijalankan. Tentunya dengan munggunakan asumsi-asumsi tertentu yang akhirnya akan dituangkan dalam aliran kas (cash flow) perusahaan dalam periode usaha, kemudian dinilai 
Jurnal Ilmiah Akuntansi Rahmaniyah (JIAR)

Vol. 3 No.2, Juni 2020, $52-65$

Irsan

kelayakan investasi tersebut melalui kriteria kelayakan investasi. Alat ukur yang digunakan untuk penilaian tersebut melalui pendekatan payback period (PP), Break Even Point (BEP) Net Present Value (NPV), Net benefit Cost (Net B/C), Profitability Index (PI), dan Internal Rate of Return (IRR).

\section{Penelitian Terdahulu}

Saipullah (2018), hasil penelitian menunjukkan bahwa aspek hukum usaha budidaya sarang burung walet bapak Jurni belum memenuhi syarat peraturan daerah untuk dijalankan, ditinjau dari aspek pasar dan pemasaran usaha budidaya sarang burung walet bapak Jurni layak untuk dijalankan, ditinjau dari aspek keuangan usaha budidaya sarang burung walet bapak Jurni layak untuk dijalankan, ditinjau dari aspek teknis dan teknologi usaha budidaya sarang burung walet bapak Jurni layak untuk dijalankan, dan ditinjau dari aspek lingkungan usaha budidaya sarang burung walet bapak Jurni layak untuk dijalankan.

Yuniarti dkk (2013), menganalisis kelayakan finansial usaha sarang burung walet di Kecamatan Matan Hilir Selatan Kabupaten Ketapang.. Penelitianya menggunakan analisis finansial dengan kriteria (1) Net Present Value (NPV), (2) Net Benefit Cost Ratio (Net B/C), (3) Internal Rate of Return (IRR), (4) Payback Period (PP) dan (5) Analisis Sensitivitas. Dari hasil penelitian dengan menggunakan discount factor 12\% menunjukan NPV sebesar Rp 287,642,243.80,Net B/C sebesar 2.27 dan IRR sebesar 21.79\%. Payback Period menunjukan pengembalian investasi sebesar 2.1, artinya dalam waktu 2 tahun 1 bulan. Berdasarkan kegiatan tersebut usaha sarang burung walet ini layak untuk diusahakan secara finansial. Sementara Analisis Sensitivitas didapatkan bahwa kenaikan biaya operasional, kenaikan benefit, dan penurunan benefit sebesar $10 \%$ masih layak diusahakan dan dikembangkan.

\section{METODOLOGI PENELITIAN}

\section{Rancangan Penelitian}

Desain penelitian yang dilakukan dalam penelitian ini adalah dengan pendekatan deskriptif, yang mana menurut Mukhtar, 2013, adalah sebuah metode yang digunakan peneliti untuk menemukan pengetahuan atau teori terhadap penelitian pada saat waktu tertentu. 
Jurnal Ilmiah Akuntansi Rahmaniyah (JIAR)

Vol. 3 No.2, Juni 2020, $52-65$

Irsan

\section{Lokasi Penelitian}

Lokasi penelitian dilakukan di kecamatan Lalan kabupaten Musi Banyuasin Sumatera Selatan yang mana peneliti sendiri merupakan salah satu peternak usaha walet di kecamatan tersebut.

\section{Metode Pengumpulan dan Analia Data}

Teknik pengambilan data dalam penelitian ini adalah data primer, yaitu dengan cara mengadakan teknik survey, observasi dan dengan dokumentasi. Sedangkan data diolah dengan analisis non statistik yang berupa analisa kelayakan investasi usaha rumah burung walet ditinjau dari aspek finansial melalui data-data investasi, biaya dan pendapatan. Analisis kriteria investasi tersebut dengan discounted meliputi:

(1) Payback Period (PP)

PP merupakan uji kelayakan investasi dengan cara mengukur jangka waktu pengembalian investasi. Aliran kas (cash flow) adalah dasar perhitungan yang digunakan sehingga metode perhitungan adalah discounted.

(2) Break Event Point (BEP)

BEP merupakan suatu analisa dimana keadaan usaha yang telah mencapai suatu titik tidak untung dan juga tidak rugi atau pada titik impas.

Sedangkan analisis kriteria investasi dengan discounted dengan beberapa metode penilaian meliputi:

(3) Net Present Value dari Arus Benefit dan Arus Cost (NPV)

NPV menunjukkan keuntungan yang akan diperoleh selama umur investasi dan merupakan selisih atau varian antara nilai yang sekarang dari manfaat dengan biaya pada tingkat diskonto tertentu.

(4) Profitability Index (PI)

Metode Profitability Index (PI) atau Desirability Index (DI) adalah metode yang menghitung perbandingan antara nilai sekarang penerimaan kas bersih di masa yang akan datang (proceeds) dengan nilai sekarang investasi (outlays).

(5) Net Benefit/Cost Ratio (Net B/C)

Net B/C merupakan metode yang membandingkan jumlah NPV positif dengan NPV negatif. Hasil perhitungannya dapat menggambarkan benefit yang akan diperoleh berapa kali lipat dari cost yang dikeluarkan. 
Jurnal Ilmiah Akuntansi Rahmaniyah (JIAR)

Vol. 3 No.2, Juni 2020, $52-65$

Irsan

(6) Internal Rate of Return (IRR)

IRR adalah metode untuk menghitung tingkat bunga yang dapat menyamakan antara present value dari semua aliran kas masuk dengan aliran kas keluar dari suatu investasi.

\section{HASIL DAN PEMBAHASAN}

\section{Hasil Penelitian}

Berdasarkan hasil survey, observasi dan melalui catatan-catatan dan dokumentasi yang penulis miliki, untuk membangun sebuah konstruksi rumah burung walet (RBW) dengan bangunan permanen ukuran 4 meter x 12 meter x 3 lantai di kecamatan Lalan kabupaten Musi Banyuasin Sumatera Selatan dibutuhkan dana investasi awal dan amortisasi pada tabel 1 sebagai berikut:

Tabel 1.

Dana Investasi dan Amortisasi RBW ukuran 4 x 12 x 3 Lantai

\begin{tabular}{|c|c|c|c|c|c|}
\hline NO. & INVESTASI & JUMLAH & NILAISISA & UMUR EKONOMIS & PENUSUTAN/BLN \\
\hline 1 & Pembangunan Rumah Burung walet & 165.078 .000 & 10.317 .375 & 15 Tahun & 10.317.375 \\
\hline 2 & Biaya Izin IMB & 6.480 .000 & 6.480 .000 & & \\
\hline 3 & Biaya Perlengakan RBW & 11.881.100 & 1.188 .110 & 15 Tahun & 712.866 \\
\hline 4 & Peralatan Panen & 3.000 .000 & 300.000 & 15 Tahun & 180.000 \\
\hline & TOTAL INVESTASI & 186.439 .100 & 18.285.485 & & 11.210.241 \\
\hline
\end{tabular}

Sumber: dokumentasi penulis, 2019, diolah

Selama kurun waktu tahun pertama sampai dengan tahun ke lima belas (umur proyek) terdapat biaya operasional yang terdiri dari biaya pemeliharaan berupa penyemprotan hama jamur dan bakteri di dalam RBW yang dilakukan secara rutin setiap 3 bulan sekali, biaya tenaga kerja, biaya listrik dan biaya air. Biaya operasional tersebut diprediksikan selama 15 tahun seperti dalam tabel 2 berikut: 
Tabel 2.

Dana Operasional Tahun ke1 sampai dengan Tahun ke 15

\begin{tabular}{|c|c|c|c|c|c|}
\hline Tahun & $\begin{array}{c}\text { Biaya } \\
\text { Pemeliharaan }\end{array}$ & $\begin{array}{c}\text { Upah Tenaga } \\
\text { Kerja }\end{array}$ & $\begin{array}{l}\text { Biaya } \\
\text { Listrik }\end{array}$ & Biaya Air & $\begin{array}{c}\text { Total } \\
\text { B. Operasional }\end{array}$ \\
\hline 1 & 600.000 & 1.200 .000 & 1.200 .000 & 600.000 & 3.600 .000 \\
\hline 2 & $660.000^{\prime}$ & 9.720 .000 & 1.320 .000 & 660.000 & 12.360 .000 \\
\hline 3 & $726.000^{\circ}$ & 24.300 .000 & 1.452 .000 & 726.000 & 27.204 .000 \\
\hline 4 & $798.600^{\prime \prime}$ & 24.300 .000 & 1.597 .200 & 798.600 & 27.494 .400 \\
\hline 5 & $878.460^{\circ}$ & 48.600 .000 & 1.756 .920 & 878.460 & 52.113 .840 \\
\hline 6 & $966.306^{\prime \prime}$ & 48.600 .000 & 1.932 .612 & 966.306 & 52.465 .224 \\
\hline 7 & $1.062 .937^{r}$ & 48.600 .000 & 2.125 .873 & 1.062 .937 & 52.851 .746 \\
\hline 8 & $1.169 .230^{\circ}$ & 48.600 .000 & 2.338 .461 & 1.169 .230 & 53.276.921 \\
\hline 9 & 1.286 .153 & 48.600 .000 & 2.572 .307 & 1.286 .153 & 53.744 .613 \\
\hline 10 & $1.414 .769^{r}$ & 48.600 .000 & 2.829 .537 & 1.414 .769 & 54.259 .074 \\
\hline 11 & 1.556 .245 & 48.600 .000 & 3.112.491 & 1.556 .245 & 54.824 .982 \\
\hline 12 & $1.711 .870^{\circ}$ & 48.600 .000 & 3.423 .740 & 1.711 .870 & 55.447 .480 \\
\hline 13 & $1.883 .057^{r}$ & 48.600 .000 & 3.766 .114 & 1.883 .057 & 56.132 .228 \\
\hline 14 & $2.071 .363^{r}$ & 48.600 .000 & 4.142 .725 & 2.071 .363 & 56.885 .451 \\
\hline \multirow[t]{2}{*}{15} & $2.278 .499^{r}$ & 48.600 .000 & 4.556.998 & 2.278 .499 & 57.713 .996 \\
\hline & 19.063.489 & 594.120 .000 & 38.126.978 & 19.063 .489 & 670.373 .956 \\
\hline
\end{tabular}

Sumber: dokumentasi penulis, 2019, diolah

Kemudian untuk menentukan net benefit diperliukan proyeksi produksi, estimasi harga jual sarang burung walet, dan perhitungan pajak sarang burung walet dapat dilihat dalam tabel 3 berikut: 
Tabel 3.

Proyeksi Net Benefit dan Cost

\begin{tabular}{|c|c|c|c|c|c|c|c|}
\hline Tahun & Produksi & Harga & Benefit & Tax & Amortisasi & Cost & Net Benefit \\
\hline 0 & - & & & & & 186.439 .100 & 186.439 .100 \\
\hline 1 & - & & & & 11.210 .241 & 3.600 .000 & $\begin{array}{r}14.810 .241 \\
201.249 .341\end{array}$ \\
\hline 2 & 2,4 & 13.500 .000 & 32.400 .000 & 3.240 .000 & 11.210 .241 & 12.360 .000 & 5.589 .759 \\
\hline 3 & 6,0 & 13.500 .000 & 81.000 .000 & 8.100 .000 & 11.210.241 & 27.204 .000 & 34.485 .759 \\
\hline 4 & 6,0 & 13.500 .000 & 81.000 .000 & 8.100 .000 & 11.210.241 & $27.494,400$ & 34.195.359 \\
\hline 5 & 12,0 & 13.500 .000 & 162.000 .000 & 16.200 .000 & 11.210.241 & 52.113 .840 & 82.475 .919 \\
\hline 6 & 12,0 & 13.500 .000 & $162,000.000$ & 16.200 .000 & 11.210 .241 & 52.465 .2224 & 82.124 .535 \\
\hline 7 & 12,0 & 13.500 .000 & 162.000 .000 & 16.200 .000 & 11.210.241 & 52.851 .746 & 81.738 .013 \\
\hline 8 & 12,0 & 13.500 .000 & 162.000 .000 & 16.200 .000 & 11.210 .241 & 53.276 .921 & $81,312.838$ \\
\hline 9 & 12,0 & 13.500 .000 & 162.000 .000 & 16.200 .000 & 11.210.241 & 53.744 .613 & 80.845 .146 \\
\hline 10 & 12,0 & 13.500 .000 & 162.000 .000 & 16.200 .000 & 11.210 .241 & 54.259 .074 & 80.330 .685 \\
\hline 11 & 12,0 & 13.500 .000 & 162.000 .000 & 16.200 .000 & 11.210.241 & 54.824 .982 & 79.764 .777 \\
\hline 12 & 12,0 & 13.500 .000 & 162.000 .000 & 16.200 .000 & 11.210 .241 & 55.447 .480 & 79.142 .279 \\
\hline 13 & 12,0 & 13.500 .000 & 162.000 .000 & 16.200 .000 & 11.210.241 & 56.132 .228 & 78.457.531 \\
\hline 14 & 12,0 & 13.500 .000 & 162.000 .000 & 16.200 .000 & 11.210.241 & 56.885.451 & 77.704 .308 \\
\hline 15 & 12,0 & 13.500 .000 & 162.000 .000 & 16.200 .000 & 11.210 .241 & 57.713 .996 & 76.875 .763 \\
\hline & & & 1.976 .400 .000 & 197.640 .000 & 168.153 .615 & 856.813 .056 & 955.042 .670 \\
\hline
\end{tabular}

Sumber: Dokumentasi Penulis, 2019, diolah

\section{Perhitungan Kriteria Investasi}

\section{(1) Payback Period (PP)}

Merupakan uji kelayakan investasi dengan cara mengukur jangka waktu pengembalian investasi. Aliran kas (cash flow) adalah dasar perhitungan yang digunakan sehingga metode perhitungan adalah discounted, seperti tampak pada tabel 4 berikut ini: 
Tabel 4.

Tabel Cash Flow RBW Uk. 4 x 12 x 3Lt

\begin{tabular}{crrrrr}
\hline TAHUN & NET BENEFI & PENYUSUTAN & \multicolumn{1}{c}{ KAS BERSIH } & \multicolumn{1}{c}{ DF 12\% } & PV KAS BERSIH \\
\hline 1 & -14.810 .241 & 11.210 .241 & 3.600 .000 & 0,893 & 3.214 .800 \\
2 & 5.589 .759 & 11.210 .241 & 16.800 .000 & 0,797 & 13.389 .600 \\
3 & 34.485 .759 & 11.210 .241 & 45.696 .000 & 0,712 & 32.535 .552 \\
4 & 34.195 .359 & 11.210 .241 & 45.405 .600 & 0,636 & 28.877 .962 \\
5 & 82.475 .919 & 11.210 .241 & 93.686 .160 & 0,567 & 53.120 .053 \\
6 & 82.124 .535 & 11.210 .241 & 93.334 .776 & 0,507 & 47.320 .731 \\
7 & 81.738 .013 & 11.210 .241 & 92.948 .254 & 0,452 & 42.012 .611 \\
8 & 81.312 .838 & 11.210 .241 & 92.523 .079 & 0,404 & 37.379 .324 \\
9 & 80.845 .146 & 11.210 .241 & 92.055 .387 & 0,361 & 33.231 .995 \\
10 & 80.330 .685 & 11.210 .241 & 91.540 .926 & 0,322 & 29.476 .178 \\
11 & 79.764 .777 & 11.210 .241 & 90.975 .018 & 0,287 & 26.109 .830 \\
12 & 79.142 .279 & 11.210 .241 & 90.352 .520 & 0,257 & 23.220 .598 \\
13 & 78.457 .531 & 11.210 .241 & 89.667 .772 & 0,229 & 20.533 .920 \\
14 & 77.704 .308 & 11.210 .241 & 88.914 .549 & 0,205 & 18.227 .483 \\
15 & 76.875 .763 & 11.210 .241 & 88.086 .004 & 0,183 & 16.119 .739 \\
\hline
\end{tabular}

Sumber: dokumentasi penulis, 2019, diolah

Investasi RBW ukuran 4 X 12 X 3 LT

Rp 186.439.100

Kas bersih tahun ke 1

Rp - 3.600.000

Rp 190.039.100

Kas bersih tahun ke 2

$\underline{\mathrm{Rp} \quad 16.800 .000}$

$\mathrm{Rp} 173.239 .100$

Kas bersih tahun ke 3

$\underline{\mathrm{Rp} \quad 45.696 .000}$

Rp 127.543.100

Kas bersih tahun ke 4

Rp 45.405 .600

Rp 82.137.500

Kas bersih tahun ke 5 adalah sebesar Rp 82.137.500/93.686.160 x 12 bulan

$=10,52$ bulan atau 11 bulan.

Dari perhitungan di atas diperoleh jangka waktu pengembalian investasi RBW ukuran 4 X 12 X 3 Lantai tersebut adalah selama 4 tahun 11 bulan.

\section{(2) Break Event Point (BEP)}

BEP adalah keadaan usaha yang telah mencapai suatu titik tidak untung dan juga tidak rugi atau pada titik impas.

$$
\begin{aligned}
& \mathrm{BEP}=\frac{F C}{P-V C} \\
& \begin{array}{c}
\mathrm{BEP}=\frac{19.063 .489+38.126 .978+19063.489+168.153615}{13.500 .00-\frac{9.720 .000+3.240 .000}{2,4 k g}} \\
=30,17377421 \mathrm{~kg} \text { atau } 30,17 \mathrm{~kg}
\end{array}
\end{aligned}
$$




$$
\mathrm{BEP}=\frac{244.407 .571}{1-\left(\frac{5.400 .000}{13.500 .000}\right)}=\frac{244.407 .571}{0,6}=\mathrm{Rp} 407.345 .952,-
$$

\section{(3) Net Present Value dari Arus Benefit dan Arus Cost (NPV)}

NPV menunjukkan keuntungan yang akan diperoleh selama umur investasi dan merupakan selisih atau varian antara nilai yang sekarang dari manfaat dengan biaya pada tingkat diskonto tertentu.

$$
\begin{aligned}
\text { NPV } & =\text { Total PV Kas Bersih }- \text { PV Investasi } \\
& =\operatorname{Rp} 418.340 .774-\text { Rp 186.439.100 = Rp 231.901.674 (NPV positif) }
\end{aligned}
$$

\section{(4) Profitability Index (PI)}

Profitability Index (PI) adalah metode yang menghitung perbandingan antara nilai sekarang penerimaan kas bersih di masa yang akan datang (proceeds) dengan nilai sekarang investasi (outlays).

$$
\begin{aligned}
& \text { PI }=\frac{\text { Total } P V \text { Kas Bersih }}{P V \text { Investasi }} \\
& \text { PI }=\frac{418.340 .774}{186.439 .100}=2,2 \text { kali }
\end{aligned}
$$

\section{(5) Net Benefit/Cost Ratio (Net B/C)}

Net B/C merupakan metode yang membandingkan jumlah NPV positif dengan NPV negatif. Hasil perhitungannya dapat menggambarkan benefit yang akan diperoleh berapa kali lipat dari cost yang dikeluarkan. Dari data-data pada taDari data-data pada tabel 3 dapat dihitung Net B/C sebagai berikut:

$$
\text { NetB /C }=\frac{\sum_{t=0}^{n} \frac{(B t-C t)}{(1+i)}(+)}{\sum_{t=0}^{n} \frac{(B t-C t)}{(1+i)}(-)}
$$

Net $B / C=\frac{995.042 .670}{201 \cdot 249.341}=4,75$ 


\section{(6) Internal Rate of Return (IRR)}

Internal Rate of Return (IRR) adalah metode untuk menghitung tingkat bunga yang dapat menyamakan antara present value dari semua aliran kas masuk dengan aliran kas keluar dari suatu investasi. seperti pada tabel 5 berikut:

Tabel 5.

Nilai IRR Usaha RBW

\begin{tabular}{|c|c|c|c|c|c|}
\hline TAHUN & KAS BERSIH & DF $26 \%$ & PV KAS BERSIH & DF $27 \%$ & PV KAS BERSIH \\
\hline 1 & 3.600 .000 & 0,800 & 2.880 .000 & 0,787 & 2.833 .200 \\
\hline 2 & 16.800 .000 & 0,640 & 10.752 .000 & 0,620 & 10.416 .000 \\
\hline 3 & 45.696 .000 & 0,512 & 23.396 .352 & 0,488 & 22.299 .648 \\
\hline 4 & 45.405 .600 & 0,410 & 18.598 .134 & 0,384 & 17.435 .750 \\
\hline 5 & 93.686 .160 & 0,328 & 30.700 .955 & 0,303 & 28.386 .906 \\
\hline 6 & 93.334 .776 & 0,262 & 24.463 .045 & 0,238 & 22.213 .677 \\
\hline 7 & 92.948 .254 & 0,210 & 19.491 .249 & 0,188 & 17.474 .272 \\
\hline 8 & 92.523 .079 & 0,168 & 15.525 .373 & 0,148 & 13.693 .416 \\
\hline 9 & 92.055 .387 & 0,134 & 12.353 .833 & 0,116 & 10.678 .425 \\
\hline 10 & 91.540 .926 & 0,107 & 9.831 .495 & 0,092 & 8.421 .765 \\
\hline 11 & 90.975 .018 & 0,086 & 7.814 .754 & 0,072 & 6.550 .201 \\
\hline 12 & 90.352 .520 & 0,069 & 6.207 .218 & 0,057 & 5.150 .094 \\
\hline 13 & 89.667 .772 & 0,055 & 4.931 .727 & 0,045 & 4.035 .050 \\
\hline 14 & 88.914 .549 & 0,044 & 3.912 .240 & 0,035 & 3.112 .009 \\
\hline \multirow[t]{2}{*}{15} & 88.086 .004 & 0,035 & 3.100 .627 & 0,028 & 2.466 .408 \\
\hline & & & 188.199.002 & & 169.500 .421 \\
\hline
\end{tabular}

Sumber: dokumentasi penulis, 2019, diolah

$$
\begin{aligned}
& \text { NPV Positif } \\
& \text { NPV }=188.199 .002-186.439 .100=1.759 .902 \\
& \text { NPV Negatif } \\
& \text { NPV }=169.500 .421-186.439 .100=-16.938 .679 \\
& \text { IRR }=i 1+\frac{N P V_{1}}{N P V_{1}-N P V_{2}}\left(i_{2}-i_{1}\right) \\
& I R R=0.26+\left[\frac{1.759 .902}{1.759 .902+16.938 .679}(0,27-0,26)\right]=0,26 \text { atau } 26 \%
\end{aligned}
$$

\section{Pembahasan}

\section{(1) Payback Period (PP)}

Payback period (PP) adalah suatu indikator untuk mengetahui seberapa lama biaya investasi usaha yang dikeluarkan akan kembali melalui keuntungan yang diperoleh atas usaha tersebut Berdasarkan hasil perhitungan payback period 
Jurnal Ilmiah Akuntansi Rahmaniyah (JIAR)

Vol. 3 No.2, Juni 2020, $52-65$

Irsan

pada usahaRBW ukuran 4 X 12 X 3 LT di atas menunjukkan sebesar 4,11. artinya pengembalian investasi berlangsung dalam waktu 4 tahun 11 bulan sehingga usaha ini dinilai cukup baik untuk dilaksanakan karena payback periode $<$ dari umur proyek.

\section{(2) Break Event Point (BEP)}

Break Event Point (BEP) adalah analisa dimana keadaan usaha yang telah mencapai suatu titik tidak untung dan juga tidak rugi atau pada titik impas. Dari hasil perhitungan BEP di atas diperoleh nilai titik impas pada posisi produksi sarang walet sebanyak 30,17 $\mathrm{kg}$ atau penjualan pada nilai $\mathrm{Rp} 407.345 .952,-$. Artinya usaha RBW akan mendapat keuntungan apabila produksi sarang walet mencapai lebih dari 30,17 kg dan akumulasi penjualan diatas Rp 407.345.952,--

\section{(3) Net Present Value (NPV)}

Net Present Value (NPV) adalah merupakan nilai sekarang dari selisih antara biaya dan manfaat. Suatu usaha dikatakan bermanfaat dan layak untuk di laksanakan apabila nilai NPV lebih besar dari 0 sedangkan apabila NPV sama dengan 1 artinya mengembalikan sebesar biaya yang dikeluarkan, sehingga keputusan untuk meneruskan usaha sangat tergantung pada pengelola, akan dilaksanakan atau tidak. Berdasarkan hasil perhitungan pada usaha RBW di atas menunjukkan NPV sebesar Rp 231.901.674 dan bernilai positif. Pada tingkat suku bunga 12\% dari hasil NPV yang lebih besar dari nol tersebut maka usaha dikatakan layak untuk dilaksanakan.

\section{(4) Profitability Index (PI)}

Profitability Index (PI) adalah metode yang menghitung perbandingan antara nilai sekarang penerimaan kas bersih masa yang akan datang dengan nilai sekarang investasi. Jika PI > dari 1 maka usaha dapat dikatakan layak dan menguntungkan, tetapi jika < dari 1 maka usaha dinyatakan tidak layak. Dari hasil perhitungan profitability index didapatkan nilai sebesar 2,2 yang berarti bernilai lebih dari 1. Dengan demikian perputaran investasi yang ditanamkan berdasarkan kas bersih yang dihasilkan selama jangka waktu yang diinginkan pada usaha rumah burung walet di kecamatan Lalan kabupaten Musi banyuasin layak untuk dijalankan dan berpotensi menguntungkan. 


\section{(5) Net Benefit/Cost Ratio (Net B/C)}

Net B/C adalah membandingkan jumlah NPV positif dengan NPV negatif. Hasil perhitungannya dapat menggambarkan benefit yang akan diperoleh berapa kali lipat dari cost yang dikeluarkan Berdasarkan hasil perhitungan Net B/C ratio di atas pada faktor diskonto $12 \%$ adalah sebesar 4,75 . Dengan kata lain dapat dijelaskan bahwa setiap pengeluaran sekarang sebesar Rp 1 akan memberikan manfaat (benefit) sebesar Rp. 4.75 kali lipat dari cost yang dikeluarkan. Nilai Net B/C ratio ini > 1 maka usaha RBW menguntungkan dan layak untuk dilaksanakan.

\section{(6) Internal Rate of Return (IRR)}

Internal Rate of Return (IRR) merupakan metode kelayakan investasi dengan menyamakan present value aliran kas dengan present value investasi. Hasil perhitungan IRR dari analisis di atas dengan tingkat discount factor (df) $26 \%$ dan $27 \%$ didapatkan hasil 26\%. Ini artinya nilai IRR lebih besar dari tingkat suku bunga pinjaman saat ini yaitu $12 \%$, dengan demikian usaha RBW ini layak untuk dijalankan.

\section{SIMPULAN DAN SARAN}

\section{Simpulan}

Ditinjau dari Aspek finansial, kelayakan usaha rumah burung walet (RBW) ukuran 4 x 12 meter x 3 lantai di kecamatan Lalan kabupaten Musi Banyuasin dari hasil perhitungan dan analisis, diperoleh payback periode pada tingkat pengembalian investasi selama 4 tahun 11 bulan, cukup cepat dari umur proyek yang direncanakan selama 15 tahun. Break event point pada produksi sebanyak 30,17 kg atau penjualan sebesar Rp407.345.952,-. Perhitungan hasil net present value dikategorikan layak karena nilai NPV yang diperoleh $>0$. Hasil dari perhitungan profitability Index sebesar 2,2 lebih besar (>) dari 1 dinyatakan layak. Perhitungan net benefit/cost ratio sebesar 4,7 berarti lebih dari 1 maka usaha RBW dinyatakan menguntungkan dan layak dilaksanakan. Hasil perhitungan internal rate of return yang diperoleh dinyatakan layak karena nilai IRR > bunga pinjaman. 


\section{Saran}

Walaupun payback periode pada tingkat pengembalian investasi selama 4 tahun 11 bulan cukup cepat dari umur proyek yang direncanakan selama 15 tahun sebaiknya payback period tersebut bisa di perpendek jika pola kebiasaan buruk peternak walet yang selalu memusnahkan telur-telur walet dengan tujuan jangka pendek untuk memanen sarang burung walet yang lebih banyak, padahal tindakan demikian dapat menggangu perkembangan populasi burung di masa yang akan datang dan hal ini akan berpengaruh terhadap produksi sarang burung walet ke depannya dan berpengaruh pula pada panjang atau pendeknya tingkat pengembalian investasi.

Untuk pengembangan penelitian selanjutnya dapat menambah variabel dari aspek-aspek lain yang sifatnya non finansial.

\section{DAFTAR PUSTAKA}

Abdullah.HM. Ma'ruf. 2017. Studi Kelayakan Bisnis. Cetakan 1, Aswaja Pressindo, Yogyakarta.

Kasmir dan Jakfar. 2014. Studi Kelayakan Bisnis Edisi Revisi. Prenadamedia Group. Jakarta.

Mukhtar, 2013. Metode Penelitian Deskriftif Kualitatif. GP Press Group. Jakarta.

Purwana. D., Hidayat. N. 2017. Studi Kelayakan Bisnis. Cetakan ke 2, PT Rajagrafindo Persada. Depok.

Saipullah. 2018. Analisis Kelayakan Usaha Budidaya Sarang Burung Walet Di Kecamatan Penyinggahan Kabupaten Kutai Barat (Studi Kasus Usaha Sarang Burung Walet Bapak Jurni): eJournal Administrasi Bisnis, 2018, ISSN 2355- 5408.

Saparudin. 2012. Pertumbuhan Ekonomi. (Accesed 22 Juli 2018), http://edunomic.net/index.php/articles/1-pertumbuhanekonomi.

Yuniarti, Vina, dkk, 2013. Analisis Kelayakan Finansial Usaha Burung Walet (Colacallia fuciphaga) Di Kecamatan Matan Hilir Selatan Kabupaten Ketapang: Sosial Ekonomi Pertanian Jurnal Agribisniis,. Tanjungpura. 